\title{
THE ISPRS STUDENT CONSORTIUM: SUSTAINING RELEVANCE AND CREATING SHARED VISIONS FOR THE YOUTH
}

\author{
S. R. Reyes ${ }^{1}$, A. K. M. Jaojoco ${ }^{2}$, C. Cruz $^{3}$, C. Jjuuko ${ }^{4}$, M. Üstüner ${ }^{5}$, J. C. K. Chow ${ }^{6}$ and S. Guliyeva ${ }^{7}$ \\ ${ }^{1}$ United Nations University - Institute for the Advanced Study of Sustainability, \\ 5 Chome-53-70 Jingumae, Shibuya City, Tokyo, Japan - sherylrose.reyes@ gmail.com \\ ${ }^{2}$ Center for Conservation Innovations, Unit 208 Civic Prime Building, Civic Drive, Filinvest Corporate City, \\ Alabang, Muntinlupa City, Philippines \\ ${ }^{3}$ Dublin City University St. Patrick's Campus, Drumcondra, Dublin 9, Ireland \\ ${ }_{4}$ Makerere University, University Rd, Kampala, Uganda \\ ${ }^{5}$ Yildiz Technical University, Department of Geomatic Engineering, Istanbul, Turkey \\ ${ }^{6}$ University of Calgary, Calgary Canada \\ ${ }^{7}$ Aerospace Monitoring of Environment Department, National Aviation Academy, Mardakan av.30, Baku, Azerbaijan
}

\section{Commission V}

KEY WORDS: ISPRS SC, youth, student organization, shared visions, summer schools, webinars, newsletters

\begin{abstract}
:
The ISPRS Student Consortium (ISPRS SC) continues to engage the youth in many activities aligned with the mission and vision of ISPRS. For the term 2016 - 2020, the ISPRS SC strengthened its foundations through collaboration within the ISPRS Council and Technical Commission V, and increasing its presence in various ISPRS events. The Consortium Board introduced several changes in the organization: (1) re-designed the official logo, which was used in different communication and media, (2) revision of the Consortium's Statutes, (3) continued the legacy of the summer schools through a new set of guidelines that coordinated all summer schools organized within ISPRS, (4) launched the Webinar Series, (5) repackaged the Newsletter into SpeCtrum, (6) introduction of two new awards, (7) hosting of a three-day Youth Forum in the ISPRS Congress and (8) the introduction of the ISPRS SC Student Chapters. A total of 13 issues had been published under SpeCtrum, two of which featured the ISPRS and an outstanding special issue on Women in Remote Sensing and Geospatial Information that received over 500 reads overnight. The SpeCtrum continued to seek experts, professors and contributors who willingly shared their work and inspire the youth. SpeCtrum had been publishing high quality articles and had been featuring outstanding scientists and researchers in the fields of remote sensing, photogrammetry and spatial information science. The Consortium also launched the Webinar Series and kicked off with an introduction on Google Earth Engine and followed by the applications of deep learning in remote sensing in 2020. For this term, a total of 16 summer schools were hosted across the globe, including one hosted under the ISPRS Education and Capacity Building Initiatives in 2018. The Consortium also partnered with international organizations such as Geo-informatics and Space Technology Development Agency, ASEAN Research and Training Center for Space Technology and Applications and the local chapters of the IEEE - Geosciences and Remote Sensing Society Young Professionals (IEEE - GRSS YP) in Brazil. The members of the Consortium had been increasing in the past year, especially with its increased presence in various social media platforms. The Consortium envisions a future, where the younger generation takes the lead and engages in relevant social and global issues and contributing significantly to the scientific community. As a student and youth organization, it aims to continue to develop more ways of knowledge transfer, capacity building and establishing professional networks to prepare students and young professionals for a future of collaboration and cooperation.
\end{abstract}

\section{INTRODUCTION}

The International Society for Photogrammetry and Remote Sensing Student Consortium (ISPRS SC, the Consortium) is the official representation of the youth in ISPRS (the Society). The Consortium is comprised of students and young professionals with common interests and goals aligned within the Society in the areas of photogrammetry, remote sensing and spatial information science. The official logo used by the Consortium at present is a redesigned version of the original logo and is currently being used in all the communication and media of the organization.

This paper aims to describe the current structure of the Consortium, which is based on the newest Statutes approved by the ISPRS Council in 2019. It will also describe the current activities of the Consortium, their status and how these activities have been contributing to the growth of the organization. Lastly, this paper will discuss the initiatives and efforts taken by the Consortium in developing shared visions, encouraging the increased involvement of the youth in the scientific community and raising awareness about global and social issues.

\subsection{Mission and vision}

The Society and the Consortium share the same vision in supporting global research, development and application of imaging and geospatial information to improve decision-making, sustain communities, and enhance quality of life around the world.

The main purpose of the Consortium is to link students, young researchers and professionals worldwide, interested in photogrammetry, remote sensing and spatial information science, to promote their scientific and professional 
developments as well as advocate imaging and geospatial science for informed, scientifically valid, and technologically sound observations of Earth conditions and trends that lead to improved and effective decision-making.

\subsection{Present structure}

Until the introduction of the new Statutes in August 2019 (ISPRS SC, 2019) the Consortium was part of the Technical Commission V (formerly Technical Commission VI), "Education and Outreach," and collaborated with the Working Group V, "Promotion of the Profession to Young People." This subsection and subsections 1.3 to 1.4 refer to information from the Statutes.

At present, the Consortium directly reports to the ISPRS Council through an Advisory Committee (AC). The Consortium is led by the Board of Directors, who controls and directs the affairs of the organization and aligns its activities and policies with the Society. There are six Elective Officers, namely, the President, Vice President, Newsletter Editor-in-Chief, Newsletter Designer, Social Media Coordinator and Website Administrator.

\subsection{Membership}

Based on the new Statutes, the different classes of membership in the Consortium are Individual, Organization, and Honorary Member. An Individual Member, i.e. a student pursuing undergraduate, master's or doctorate $(\mathrm{PhD})$ degrees or a young professional, is an individual involved in the science and engineering disciplines associated with imaging and geospatial information. Organization Member is either a student organization or an accredited organization involved in education and/or research in the science and engineering disciplines associated with imaging and geospatial information. An Honorary Member is an individual of high professional standing within the Society or within a sister society.

\subsection{Scope}

The Consortium promotes the Society, the profession and involvement in the scientific community to the youth in order to effectively integrate them into the activities and the structure of ISPRS. The Consortium has been organizing a number of scientific and social events to provide opportunities and platforms of exchange for the youth to establish and expand their professional networks. These events are organized specifically for students and young professionals, and costs are kept to a minimum and funding is made available whenever possible.

Since 2007, the Consortium has been publishing a Newsletter, which is the primary publication of the organization (Detchev et al., 2016). The Newsletter collects contributions from the members, interviews experts and professionals in the fields of remote sensing, photogrammetry and spatial information science. More recently, the Newsletter has been introducing themes that are not only relevant to the scientific community, but also raises awareness for specific social and global issues that can help in empowering the youth and the underrepresented groups in the profession. In addition, the Consortium maintains a social media presence that links all its members across the globe, promoting its activities and supporting the information published in the official website.
The Consortium as an international organization for the youth has been establishing connections to relevant international, regional and national organizations. These international linkages play a significant role in coordinating international and national events, improving the activities of the Consortium and maintaining cooperation to support the capacity building and educational activities of the organization.

\subsection{Current practices}

The Board of Directors currently meets once a month, to ensure the effective operation of the Consortium and to keep track of its activities throughout the year. Information dissemination and promotions are primarily implemented in the website and strongly supported by social media announcements.

The Board of Directors operates based on an annual work plan decided at the end of the previous year and specifically assigns tasks to every member of the Board of Directors. From this annual work plan, the annual report is delivered by the end of the year to identify the accomplishments and challenges encountered by the Consortium.

One of the achievements of the Board of Directors of this term is the drafting of documents related to specific activities of the Consortium to serve as guidelines and support the best practices to effectively maintain the operations of the organization. These documents are intended to provide the future Board of Directors with the necessary information to transition and continue the activities of the Consortium.

\subsection{Strengthening the connection to ISPRS}

The Consortium worked with the ISPRS Council, through the ISPRS $2^{\text {nd }}$ Vice President, and with the Technical Commission $\mathrm{V}$ for the summer school guidelines in 2017 and the new Statutes in 2019. The summer school guidelines enabled the coordination and organization of all summer schools of ISPRS through the Consortium. The new Statutes strengthened the association of the Consortium with the Society, further aligning the mission and vision of both organizations. The Consortium also contributed to the ISPRS eBulletin through the submission of past event reports and editorials from the Consortium President in December 2018 and January 2020 (ISPRS, 2020a). The accomplishments of the Consortium from 2018 - 2019 were also published in the ISPRS Biennial Report (ISPRS, 2020b).

The Consortium was also one of the first recipients of the grants under the 2018 ISPRS Education and Capacity Building Initiatives (ISPRS, 2018). The event entitled, Making Opportunities to Initiate Valuable Alliance Through Experiential Learning (MOTIVATE Learning), established the collaboration and cooperation among the Consortium, Thailand's Geo-informatics and Space Technology Development Agency (GISTDA) and the ASEAN Research and Training Center for Space Technology and Applications (ARTSA). 


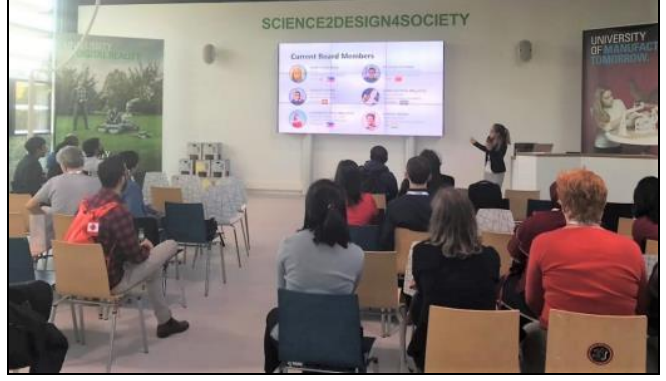

Figure 1. Charmaine Cruz, our Newsletter Editor-in-Chief, presented the ISPRS SC to the attendees of the Students and

Young Professionals Night in the ISPRS Geospatial Week 2019.

The Consortium also hosted the Students and Young Professionals Night in the ISPRS Geospatial Week 2019 (Figure 1) held in Enschede, The Netherlands an informal meetup for the young participants of the event as well as the supporters of the Consortium. This was held in the Ideate Room, DesignLab at the University of Twente.

\section{SUSTAINING RELEVANCE THROUGH CONTRIBUTIONS}

\subsection{Summer Schools}

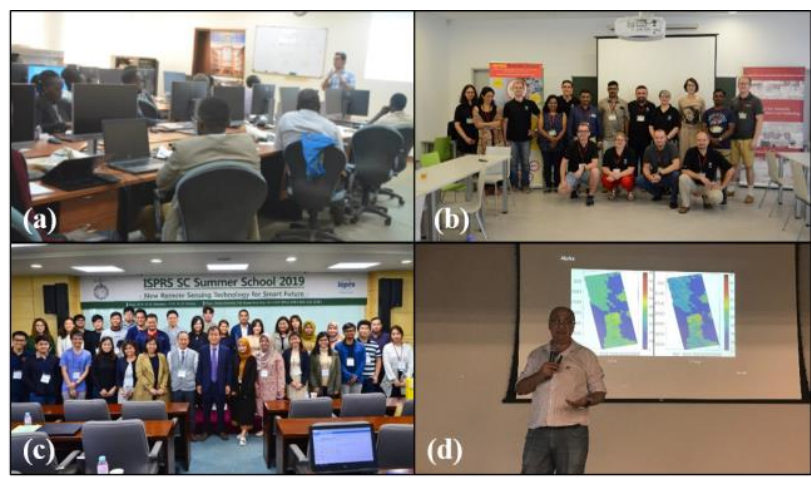

Figure 2. The summer schools held in (a) Uganda, (b) Poland,

(c) South Korea and (d) Brazil in 2019.

One of the major activities of the Consortium is the summer school (Figure 2), which aims to provide opportunities for students and young researchers to participate in a series of lectures, practical sessions, technical tours, and social events at a minimum cost (Gong et al., 2017). It also provides a venue to build relationships and strengthen the network among participants, resource speakers, professors and experts from the host country, which can potentially stimulate future collaborations and introduce the youth to the international scientific community.

To ensure consistency in the organization of the summer schools and to assist local organizers in preparing for the summer schools, a set of guidelines was prepared by the Consortium and the Society, which was approved in December 2017 (ISPRS SC, 2017).

As of 2019, a total of 12 summer schools were organized since the beginning of the term in 2016 (Appendix, Table 1).

\subsection{Webinars}

Webinars are one of the commonly used ways of reaching out to a worldwide audience through seminars hosted over the web, providing the audience an opportunity to interact with lecturers, professors, resource speakers and moderators through state-ofthe-art software at a minimum cost (Vyas and Koenig, 2014).

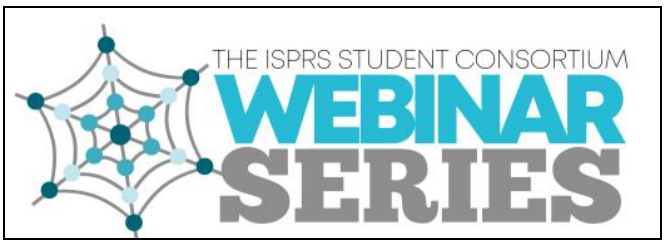

Figure 3. The promotional banner of the ISPRS SC Webinar Series.

In 2018, the ISPRS SC launched its Webinar Series (Figure 3) as a way of providing knowledge and up-to-date information to its members. The Webinar Series (ISPRS SC, 2019) aims to introduce experts and scientists from the Society to the members of the Consortium. Specifically, the objectives of the webinar series are the following: (1) to diversify the means of information and knowledge dissemination within the Consortium, (2) to provide a venue to further connect the Consortium members with the wider ISPRS community of scientists and professionals and to learn more about the Technical Commissions of ISPRS, and (3) to introduce and provide an opportunity of dynamic interaction and information exchange with ISPRS distinguished experts and scientists in the fields of remote sensing, photogrammetry and spatial information science to the Consortium members. At present, the Board of Directors creates a poll over social media to identify the most interesting topic that the members would like to have in the Webinar Series.

The first webinar of the Webinar Series was held in September 2018, entitled "Introduction to Google Earth Engine." The lecture was given by Dr. Nicholas Clinton and 167 students and young researchers participated.

The second webinar focusing on the theme of deep learning for remote sensing applications and computer vision was held in February 2020. The topic was on "Deep Learning for Remote Sensing and Photogrammetric Analysis." The featured lecturer was Dr. Konrad Schindler of ETH Zurich, who was also a recipient of the prestigious U.V. Helava Award in 2012. This recent webinar was attended by about 91 participants and included a very dynamic question and answer session among the lecturer and the participants.

The next lecturer to follow-up on this current theme will be Dr. Devis Tuia of the University of Wageningen and a member of both ISPRS and IEEE Geosciences and Remote Sensing Society (IEEE - GRSS).

The webinars were live-streamed over the ISPRS SC YouTube channel and previous recordings can be accessed online (ISPRS SC YouTube Channel: http://bit.ly/3bVPLH3).

\subsection{Newsletters}

The Consortium began publishing the ISPRS SC Newsletter in collaboration with students and young professionals aiming to disseminate the activities of the organization and share interesting articles and interviews related to the organization since 2007. The Newsletter is the main publication of the ISPRS $\mathrm{SC}$, with all issues available online (sc.isprs.org/scnewsletter.html), and printed copies are made available at certain ISPRS events. The Newsletter features reports about past student activities and the organization's events, interviews 
with experts and practitioners in the fields of remote sensing, photogrammetry, and spatial information sciences, technical papers, upcoming events, and opportunities.

From 2016, the Newsletter has been running for eight years. It has been one of the major modes of communication and ways of disseminating information to the members of the Consortium. However, the Newsletter also needs to keep up with the changing time, the fast-paced developments in technology, and the diversity of its readers. In line with this, the Board of Directors, through the President and the leadership of the Newsletter Editor-in-Chief (from 2016 - 2018), initiated the repackaging of the Newsletter.

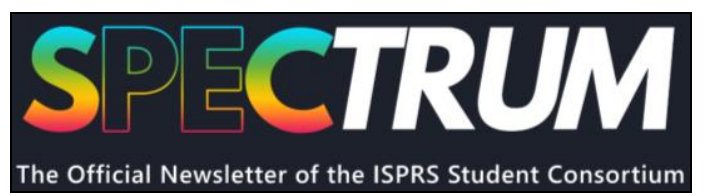

Figure 4. The design for SpeCtrum: The Official Newsletter of the ISPRS Student Consortium

The outcome of the discussion was SpeCtrum - indicative of the electromagnetic spectrum, which is one of the principles in remote sensing, and at the same time, containing the initials $\mathrm{S}$ and $\mathrm{C}$, to represent the Student Consortium (Figure 4). In addition to the significance of SpeCtrum in the discipline, the name is also an epitome of diversity, and now that the scientific community has welcomed the era of multidisciplinary, interdisciplinary, and even transdisciplinary research, this publication aims to cover a wide range of applications related to our profession. Volume 11 has marked the beginning of the repackaged Newsletter.

The issues of SpeCtrum feature several sections, some of which are also named after common terms in the disciplines of remote sensing, photogrammetry, and spatial information sciences, and some other sections retained from the original Newsletter. "Backsight" is the section featuring past event reports. "Spotlights" are feature articles about important events and scientific articles related to the theme of the Newsletter issue. "I-F-O-V", an acronym for the instantaneous field of view, is recreated in the Newsletter as Important-Focused-OutstandingValuable, for the interviews with professors and experts renowned in the community. "In the Horizon" is a list of upcoming events relevant to our profession. "Foresight" is about upcoming ISPRS and ISPRS SC events and opportunities for the members.

With the repackaged SpeCtrum, the Newsletter aims to deliver timely issues that are scientifically and socially relevant. This publication also shares high quality research articles to encourage more members to contribute their scientific work and personal experiences. As of this writing, a total of 14 issues were published since the beginning of the term (Appendix,Table 2).

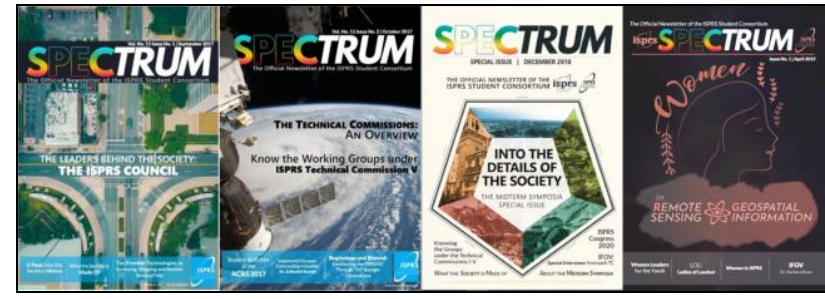

Figure 5. The special issues of SpeCtrum, the official Newsletter of the ISPRS Student Consortium.

The SpeCtrum published three special issues (Figure 5) about ISPRS in order to help the members become more familiar with the Society - the first issue "The Leaders Behind the Society: The ISPRS Council" and the midterm symposia special issue, "Into the Details of the Society." The promotion of gender diversity and women empowerment in the fields of science, technology, engineering and mathematics (STEM) prompted the publication of the special issue on "Women in Remote Sensing and Geospatial Information," which is by far, the most read and shared issue of the SpeCtrum (also in Figure 5).

\subsection{Social media}

The use of social networking platforms is one way of promoting awareness and expanding the reach of the Consortium, through sharing relevant and updated information (e.g., important dates of the summer schools, publication of the Newsletter, ISPRS events and other activities) to its members, and building connections within the group. Currently, the ISPRS SC has four social media accounts: (1) Facebook, (2) Twitter, (3) LinkedIn, and (4) Instagram, and is being managed by the Social Media Administrator. Table 1 shows the current number of followers/members of the ISPRS SC social media accounts.

Table 1. The number of connections of the ISPRS SC social media accounts as of May 2020.

\begin{tabular}{|c|c|}
\hline Social Media Account & \# of Connections* \\
\hline $\begin{array}{c}\text { Facebook } \\
\text { (ISPRS Student Consortium Group) }\end{array}$ & 6,782 \\
\hline $\begin{array}{c}\text { Twitter } \\
\text { (@ISPRS_SC) }\end{array}$ & 1,029 \\
\hline $\begin{array}{c}\text { Instagram } \\
\text { (@isprssc) }\end{array}$ & 237 \\
\hline $\begin{array}{c}\text { Linkedin } \\
\text { (ISPRS Student Consortium) }\end{array}$ & 189 \\
\hline
\end{tabular}

*Connections refer to group members in Facebook, followers in Instagram and Twitter, and connections on LinkedIn 


\subsection{ISPRS Education and Capacity Building Initiatives: MOTIVATE Learning}

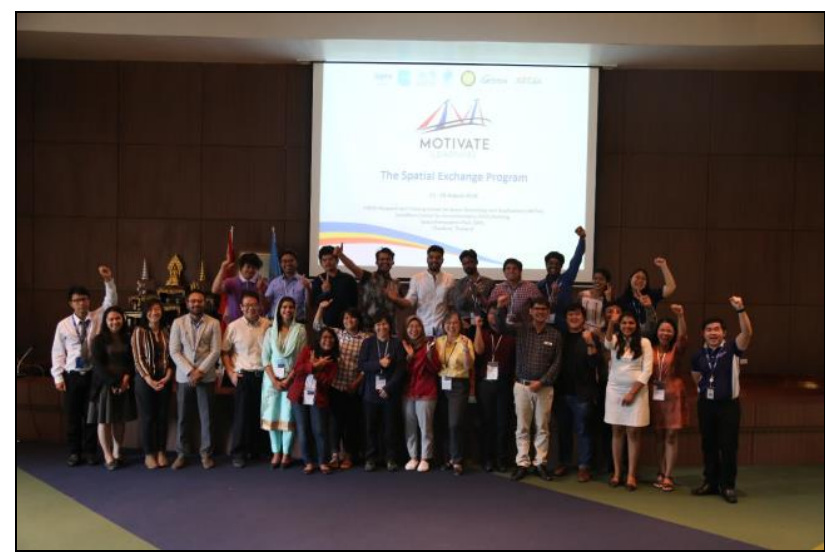

Figure 6. The participants of the Spatial Exchage Programme under MOTIVATE Learning.

The Consortium continues to focus on engaging the youth and young professional's community of the ISPRS to strengthen its network and establish new linkages. These are normally achieved through organizing activities and events that are relevant to the interests of the youth of today. Keeping this in mind, the Consortium, the Geo-informatics and Space Technology Development Agency (GISTDA) and the ASEAN Research and Training Center for Space Technology and Applications (ARTSA) in Thailand developed the project called MOTIVATE Learning (Figure 6). This project was designed to build the capabilities of students and young professionals in the fields of remote sensing, photogrammetry and spatial information sciences through two programs, namely: (1) an ISPRS SC Summer School + Hackathon (SSH) and (2) The Spatial Exchange Program (SEP). MOTIVATE Learning was conducted over the course of two weeks, from August $6-20$, 2018, in Space Krenovation Park (SKP), Chon Buri, Thailand.

Twenty applicants coming from eight different countries (i.e. China, India, Indonesia, Malaysia, Myanmar, Pakistan, Philippines and Thailand) participated in the first program of MOTIVATE Learning. The first program was further subdivided into two parts: the ISPRS SC Summer School, included a series of lectures on sustainable development, remote sensing and spatial information science, and; the beginner's Hackathon - a 2-day sprint-like event to develop a web-based tool implementing a systematic solution, specifically designed to address their identified research problem. Aside from lectures, the Hackathon brought more focus on the break-out sessions and the practical sessions that challenged the students to bring innovative ideas utilizing geospatial information.

The second program, the Spatial Exchange Program, was exchange program hosted for eight days that gave opportunities to the successful applicants to receive guidance and mentoring from invited senior researchers from various universities and organizations, and; GISTDA professionals to broaden their knowledge of geospatial technologies in diverse fields of application. Sixteen applicants from various countries such as India, Indonesia, Myanmar, Pakistan and Philippines were selected to participate in the SEP. The topics of interest in this program included (1) Mapping Using UAVs, (2) Synergistic Approach to Mapping Using Remote Sensing and GIS: Disaster Monitoring, (3) Synergistic Approach to Mapping Using Remote Sensing and GIS: Environment, and (4) Geo Big Data for Disaster Management.
The direct outputs of MOTIVATE learning from the SSH program were innovative ideas on the utilization of geospatial information for (1) tourism, (2) public health, (3) infrastructure and transportation, and (4) emergency response. Equally significant output from the SEP includes researches in disaster risk reduction, environment monitoring, emergency decision support system and carbon stock assessment. Furthermore, some of the participants of MOTIVATE Learning were able to present their accomplished work in the Student Session of the TC V Midterm Symposium in Dehradun, India. These tangible outputs from the participants set the foundation to the achieved outcomes of the project which included: (1) increased capacity of the students exhibited through the presentation of the design ideas for applications/tools developed through the hackathon, (2)strengthened collaboration among participants and professional networks of the Summer School + Hackathon and the Spatial Exchange Program, and (3) information, education, communication (IEC) materials to communicate science were successfully collected compiled as resources for the members of the Consortium.

\subsection{ISPRS Congress}

The ISPRS Congress is one of the biggest scientific gatherings in remote sensing, photogrammetry and spatial information science. This quadrennial event is attended by industry experts, the academia, government agencies, scientific institutions, nongovernment organizations and a great number of end users as well as other international organizations relevant or associated with ISPRS.

The ISPRS Congress is a great opportunity to meet the members of the Consortium and a general assembly is held to inform the current members about the status of the organization and to elect the next Board of Directors.

The Youth Forum has been hosted by the Consortium since its inception. The organization has regularly organized technical sessions, panel discussions and a student night within the ISPRS Congress.

In the upcoming ISPRS Congress, which has been postponed to July 2021, a three-day Youth Forum will be hosted for the very first time. In this track, there will be several activities in addition to the regular activities, which include a speed dating event to connect the youth to industry experts and different universities around the world, and a special session on women in remote sensing, photogrammetry and remote sensing that aims to gather as many women as possible in the profession to tell their stories and raise awareness about gender diversity. In addition, a summer school will be hosted prior to the ISPRS Congress.

\subsection{Awards}

With the growing number of members and increasing presence of the Consortium activities across the globe, the ISPRS Student Consortium Awards (ISPRS SC, 2020) were proposed to recognize the exemplary contributions of individuals to the organization. Many of the activities and initiatives of the Consortium have been made possible and were successful due to the support from local organizers and individuals who believe in the mission and vision of the organization. Two awards were created, namely, the Excellence and Service awards. 
The Excellence award commends students and young researchers for publishing outstanding papers in any ISPRS publication, such as journals, Annals, and Archives.

The award is given annually to the best paper demonstrating state-of-the-art applications and innovative ideas in the fields of photogrammetry, remote sensing and spatial information science. The Excellence Award is presented at the ISPRS Congress, the Geospatial Week, and at a selected Technical Commission Midterm Symposium in the subsequent calendar year.

The ISPRS Student Consortium Service award recognizes an individual who has rendered exceptional contributions to the Consortium during an ISPRS Congress term.

\section{CREATING SHARED VISIONS FOR THE YOUTH}

\subsection{Scientific and social relevance}

As the representation of the youth in the Society, the main activities of the Consortium focus primarily in engaging the students and young professionals in the scientific community. The summer schools, webinars and activities on education and capacity building have been providing opportunities to the Consortium members to connect to experts within ISPRS and to link with the global network of students and young professionals.

ISPRS also aims to contribute to a sustainable society, which means that there is a growing need to work across disciplines. This requires awareness about the possible contributions of remote sensing, photogrammetry and spatial information science in tackling global issues or initiating collaboration with other disciplines.

The Consortium is currently addressing this need by initiating themes for the summer schools and SpeCtrum that introduce relevant issues to the youth, such as sustainability, gender diversity, youth leadership in climate change and advances in the geospatial information in developing regions. In addition, the Consortium also attempts to innovate its current activities such as the summer school by introducing a hackathon, initiating an exchange program centered on mentorship and international collaboration, and webinars that enable the members to connect with experts in the profession.

It is also worth noting that the Consortium has been contributing to the capacity building in Africa through the summer schools and has featured the current advances in remote sensing and spatial information science in the region. These efforts addresses the call to promote the use of Earth observation data in Africa (Dowman and Kufoniyi, 2010).

\subsection{Student chapters}

To further strengthen the network and local presence of the Consortium, the establishment of local student chapters has been proposed. The recognized student chapters will have access to a number of resources from the Consortium that will facilitate the promotion of the organization as well as the Society and support the coordination of local events. The Consortium also expects the student chapters to inspire more youth in their respective localitites to learn more about ISPRS, participate in the activities and be part of the Consortium's future.
One of the main activities proposed for the student chapters is the hosting of virtual meetups. Inspired by the conservation community of WILDLABS (WILDLABS, 2020) these virtual meetups aim to connect the student chapters to the experts within ISPRS. The main difference of the virtual meetups from the webinars is the dynamic interaction among the members of the student chapter and the invited experts, focusing more on sharing knowledge and experiences in the profession in support of the challenges encountered by students, young professionals and early career researchers.

\subsection{International linkages}

To strengthen the presence of the organization and to promote collaboration, the Consortium continues existing partnerships and establishes new connections with similar student and youth organizations, scientific institutions and other relevant groups to the organization.

Since 2010, the Consortium has been organizing a summer school after the annual Asian Conference on Remote Sensing (ACRS). This conference is led by the Asian Association on Remote Sensing (AARS). During the conference, student activities are also organized and the Consortium has actively participated in the organization of these activities for the youth.

Since 2015, the IEEE - GRSS Young Professionals (IEEEGRSS YP) and ISPRS SC Summer School in Brazil summer school has been organized yearly, in two blocks corresponding to each organization. The summer school in 2019 was organized in partnership with the Institute for the Advanced Studies (IEAv), through the IEEE - GRSS YP Brazil Chapter, and was held during the Remote Sensing in Defense Applications (Portuguese: Simpósio de Sensoriamento Remoto de Aplicações em Defesa, SERFA) in Sorocaba, São Paulo, Brazil.

SpeCtrum also provided another avenue in connecting with experts, professors, organizations and relevant groups to the Consortium. The special issue on "Women in Remote Sensing and Geospatial Information" featured the women leaders from the FIG Young Surveyors Network (FIG YSN), the Space Generation Agency Council (SGAC), and the international and Brazil chapter of the IEEE-GRSS. In addition, two organizations promoting the visibility and empowerment of women were also featured, namely, the Ladies of Landsat and Soapbox Science.

The recent issue of SpeCtrum on the topic of climate change has featured an article for an upcoming publication from the United Nations Environment Programme (UNEP) called UN Global Environment Outlook 6 for Youth (GEO-6 for Youth, https://www.unenvironment.org/resources/assessment/globalenvironment-outlook-6-youth). The Consortium aims to help in promoting this publication as it is timely and immensely relevant because of the climate crisis and the organization believes in the leadership of the youth in pursuit of a more sustainable future. This publication is geared towards educating the youth about the current status of the environment, sustainability and the Sustainable Development Goals (SDGs), and a call to action in contributing to the solutions for the world's most pressing environmental issues.

\section{CONCLUSIONS}

The Consortium as the representation of the youth in ISPRS has been sustaining its contributions with the continued organization of events such as summer schools, exchange 
programs, social activities and webinars. The organization further promotes the profession through SpeCtrum, the official Newsletter of the ISPRS, and through various social media.

The increasing involvement of the youth in both scientific and social endeavors requires the Consortium to establish shared visions for the youth by raising awareness about relevant global and social issues as well as contributing to the scientific community, introducing local student chapters and establishing international linkages.

\section{ACKNOWLEDGEMENTS}

We, the Board of Directors, would like to express our deepest gratitude to the ISPRS Council, with a special mention to the ISPRS $2^{\text {nd }}$ Vice President, Dr. Charles Toth, and Technical Commission V President, Dr. A. Senthil Kumar for their unwavering support and great encouragement for the Consortium. We are also sincerely thankful to the ISPRS Foundation and the assistance provided by Dr. Marguerite Madden, for the financial assistance provided to the Board of Directors and the activities of the Consortium. We would also like to acknowledge the contributions of our former Board Member (2018-2019), Mr. Kinglsy Ashish. We also extend our sincerest thanks to all the organizers, partners, experts, professors, participants, enthusiasts and members of the Consortium across the globe for your contributions and support for the organization.

\section{REFERENCES}

Detchev, I., Kanjir, U., Reyes, S. R., Miyazaki, H., \& Aktas, A. F. (2016). Latest developments of the ISPRS Student Consortium. International Archives of the Photogrammetry, Remote Sensing \& Spatial Information Sciences, 41.

Gong, J., Yue, P., Woldai, T., Tsai, F., Vyas, A., Wu, H., ... \& Musikhin, I. (2017). Geoinformatics education and outreach: looking forward. Geo-spatial information science, 20(2), 209217.

Dowman, I., \& Kufoniyi, O. (2010). Policies for applying earth observation in Africa: an ISPRS perspective. International Archives of the Photogrammetry, Remote Sensing and Spatial Information Science, 38(Part 8), 1088-1093.

ISPRS (2020a). ISPRS eBulletin. Retrieved from https://www.isprs.org/news/newsletter/default.aspx. Accessed 20 February 2020.

ISPRS (2020b). ISPRS Student Consortium: Increasing Youth Engagement in ISPRS. 2018-19 Biennial Report, 29-30.

ISPRS (2018). Education and Capacity Building Initiatives. Retrieved from https://www.isprs.org/society/ecbi/ecbi2018.aspx. Accessed 20 February 2020.

ISPRS SC (2020a). Statutes. Retrieved from http://sc.isprs.org/about/isprs-sc/statutes.html. Accessed 20 February 2020.

ISPRS SC (2017). Guidelines for organizing and hosting ISPRS Student Consortium Summer Schools. Retrieved from http://sc.isprs.org/SS_guidelines.html. Accessed 20 February 2020.
ISPRS SC (2019). The ISPRS Webinar Series. Retrieved from http://sc.isprs.org/isprs_sc_webinars.html. Accessed 22 February 2020.

ISPRS SC (2020b). The ISPRS Student Consortium Awards. Retrieved from http://sc.isprs.org/index-the-isprs-SCawards.html. Accessed 22 February 2020.

WILDLABS (2020). The Virtual Meetup Archive. Retrieved from https://www.wildlabs.net/virtual-meetups. Accessed 22 February 2020.

Vyas, A., \& Koenig, G. (2014). Computer Aided Teaching in Photogrammetry, Remote Sensing, and Geomatics-A Status Review. The International Archives of Photogrammetry, Remote Sensing and Spatial Information Sciences, 40(6), 113.

\section{APPENDIX}

Table 1. ISPRS SC Summer Schools organized from the beginning of the term until the end of 2019

\begin{tabular}{|c|c|}
\hline Event Name and Dates & Theme \\
\hline $\begin{array}{l}\text { 16th ISPRS SC and WG } \\
\text { V/5 Summer School: } \\
\text { Lages, Brazil } \\
(2-6 \text { October } 2017)\end{array}$ & $\begin{array}{l}\text { Multivariate Statistics, Introduction to } \\
\text { Laser Scanning, and Image } \\
\text { Processing with Google Earth Engine }\end{array}$ \\
\hline $\begin{array}{l}\text { 38th Asian Conference on } \\
\text { Remote Sensing ISPRS SC } \\
\text { Summer School (30 } \\
\text { October 2017-3 } \\
\text { November 2017) }\end{array}$ & $\begin{array}{l}\text { Geo-processing Tools and } \\
\text { Technologies in Citizen Science }\end{array}$ \\
\hline $\begin{array}{l}\text { 18th ISPRS SC and WG } \\
\text { V/5 Summer School: } \\
\text { Santiago, Chile } \\
(13-17 \text { November } 2017)\end{array}$ & $\begin{array}{l}\text { Land Cover Assessment and } \\
\text { Monitoring Using Google Earth } \\
\text { Engine }\end{array}$ \\
\hline $\begin{array}{l}\text { ISPRS Technical } \\
\text { Commission III Midterm } \\
\text { Symposium Summer } \\
\text { School - Beijing, China (4 } \\
\text { - } 6 \text { May 2018) }\end{array}$ & $\begin{array}{l}\text { Innovative methods, theory and } \\
\text { practice of earth observation and } \\
\text { remote sensing technology for the } \\
\text { measurement and mapping of } \\
\text { complex urban environments }\end{array}$ \\
\hline $\begin{array}{l}\text { 39th Asian Conference on } \\
\text { Remote Sensing ISPRS SC } \\
\text { Summer School }(20-24 \\
\text { October 2018) } \\
\end{array}$ & $\begin{array}{l}\text { Big Geo-Sensing Data Ecosystem: } \\
\text { Theory, Processing \& Application }\end{array}$ \\
\hline $\begin{array}{l}\text { IEEE GRSS YP and } \\
\text { ISPRS SC Summer School } \\
(29 \text { October - } 1 \text { November } \\
2018)\end{array}$ & $\begin{array}{l}\text { UAV Photogrammetry and Machine } \\
\text { Learning Applications: Emerging } \\
\text { Trends and Challenges for } \\
\text { Earth Observation }\end{array}$ \\
\hline $\begin{array}{l}\text { ISPRS SC Summer School } \\
\text { in Makerere University } \\
\text { Kampala (22 - 24 July } \\
\text { 2019) }\end{array}$ & $\begin{array}{l}\text { Synthetic Aperture Radar (SAR) } \\
\text { Remote Sensing Workshop }\end{array}$ \\
\hline $\begin{array}{l}\text { ISPRS SC Summer School } \\
\text { in Wroclaw, Poland ( } 26- \\
30 \text { August 2019) }\end{array}$ & $\begin{array}{l}\text { Geospatial technologies for natural } \\
\text { environment management and } \\
\text { monitoring }\end{array}$ \\
\hline $\begin{array}{l}\text { 40th Asian Conference on } \\
\text { Remote Sensing ISPRS SC } \\
\text { Summer School }(21-25 \\
\text { October 2019) }\end{array}$ & $\begin{array}{l}\text { New Remote Sensing Technology for } \\
\text { Smart Future }\end{array}$ \\
\hline $\begin{array}{l}\text { 5th ISPRS Student } \\
\text { Consortium Summer } \\
\text { School \& IEEE GRSS } \\
\text { Young Professionals (10- } \\
14 \text { November 2019) }\end{array}$ & $\begin{array}{l}\text { Space Technology, Markets and } \\
\text { Building the New Brazilian Space } \\
\text { Age }\end{array}$ \\
\hline
\end{tabular}


Table 2. The issues and themes of the ISPRS SC Newsletter published since the beginning of the term until the end of the year 2019. (Copies are available online: sc.isprs.org/scnewsletter.html)

\begin{tabular}{|c|c|c|c|}
\hline Volume & Issue & Month Published & Theme \\
\hline 10 & 3 & February 2017 & $\begin{array}{l}\text { Student Activities at the } \\
\text { ISPRS Congress, ACRS } \\
\text { and the new Student } \\
\text { Consortium Board }\end{array}$ \\
\hline 10 & 4 & September 2017 & $\begin{array}{l}\text { Open Source Tools for } \\
\text { RS/GIS }\end{array}$ \\
\hline 11 & 1 & September 2017 & The ISPRS Council \\
\hline 11 & 2 & October 2017 & $\begin{array}{l}\text { The Technical } \\
\text { Commissions }\end{array}$ \\
\hline 11 & 3 & February 2017 & 2017 In Review \\
\hline 11 & 4 & August 2017 & $\begin{array}{l}\text { Remote Sensing } \\
\text { Applications in Forestry }\end{array}$ \\
\hline 12 & 1 & May 2018 & $\begin{array}{l}\text { The Midterm Symposia } \\
\text { (Special Issue) }\end{array}$ \\
\hline 12 & 2 & July 2018 & $\begin{array}{l}\text { Photogrammetry and } \\
\text { Computer Vision }\end{array}$ \\
\hline 12 & 3 & September 2018 & $\begin{array}{l}\text { Remote Sensing and GIS } \\
\text { on Ecology and } \\
\text { Conservation }\end{array}$ \\
\hline 12 & 4 & January 2019 & $\begin{array}{l}\text { Citizen Science and } \\
\text { Geoinformatics }\end{array}$ \\
\hline 13 & 1 & April 2019 & $\begin{array}{l}\text { Women in Remote Sensing } \\
\text { and Geospatial Information } \\
\text { (Special Issue) }\end{array}$ \\
\hline 13 & 2 & August 2019 & $\begin{array}{l}\text { Remote Sensing of the } \\
\text { Blue Carbon Ecosystems }\end{array}$ \\
\hline 13 & 3 & December 2019 & $\begin{array}{l}\text { Advances in Remote } \\
\text { Sensing and Spatial } \\
\text { Information Science in } \\
\text { Africa }\end{array}$ \\
\hline 13 & 4 & February 2020 & $\begin{array}{l}\text { Applications of Remote } \\
\text { Sensing and Geospatial } \\
\text { Information to Climate } \\
\text { Change }\end{array}$ \\
\hline
\end{tabular}

